\title{
Otter distribution in Lithuania
}

\author{
K. Baranauskas, E. Mickevičius, S. M. Macdonald and C. F. Mason
}

The authors carried out the first field survey for otters in Lithuania, which demonstrated that the species is still widespread. With otters now rare or absent in much of western Europe, conservation strategies for the animal and its habitats in remaining eastern European strongholds must be developed.

\section{Introduction}

The otter Lutra lutra, now rare or absent over large areas of western Europe (Foster-Turley et al., 1990), has recently been found to be thriving in some parts of the east, for example in regions of Hungary (Kemenes, 1991) and the Czech Republic (Hlavác and Toman, 1993). In Byelorussia the species can still be found throughout the country (Sidorovich, 1990) while in Latvia, otters are widespread (Ozolinš and Rantinšs, 1992). In Lithuania, Maldžiūnaite (1960) published results of her study on distribution and diet during the 1950 s but since then there have been no investigations of the species. Official figures on otter distribution published by the Lithuanian Environmental Protection Department were suspected of greatly underestimating the current situation (Mickevičius, 1993) and so an initial field survey was carried out as a first step towards instigating an otter conservation programme for the country. It was also considered important to provide more detailed information on otter distribution in Lithuania so that the population of the Baltic States, together with Belarus (Byelorussia), could be considered as an integral whole in measures to conserve the species and its habitats.

\section{The study area}

Lithuania, a low-lying country on the Baltic coast, comprises $65,200 \mathrm{sq} \mathrm{km}$ and has a human population of about 4 million. There is little and localized industry while agriculture is not intensive. The country is rich in lakes and waterways and while many rivers have been regulated, with only $17,000 \mathrm{~km}$ of the total $63,700 \mathrm{~km}$ in the country still being in a natural state, riparian woodlands and speciesrich meadows are common features.

\section{Methodology}

During May and June 1993, stations throughout Lithuania were surveyed for otter presence. The field survey was carried out using the 'standard' method, which has now been employed in many European countries (see Macdonald, 1983 for details). At each station a maximum of $600 \mathrm{~m}$ of bank was searched for otter signs (namely spraints or footprints), stations being chosen where possible for ease of access. If no signs were found after a $600-\mathrm{m}$ search the station was considered negative. The efficiency of the survey method is demonstrated in Mason and Macdonald (1987). A note was made at each station of the number of signs found, of the relative suitability of the habitat in terms of providing shelter for otters and of any obvious signs of water pollution.

\section{Results}

During May and June 1993, signs of otters were found at 106 of 112 stations ( 95 per cent) surveyed throughout Lithuania (Figure 1). Signs were found within the first $50 \mathrm{~m}$ of the search at 50 per cent of the sites. A total of 1607 spraints was found at 207 sprainting sites but this included one site with 1000 spraints. Omitting this site, the mean number of 
Figure 1. Distribution of otters in Lithuania.

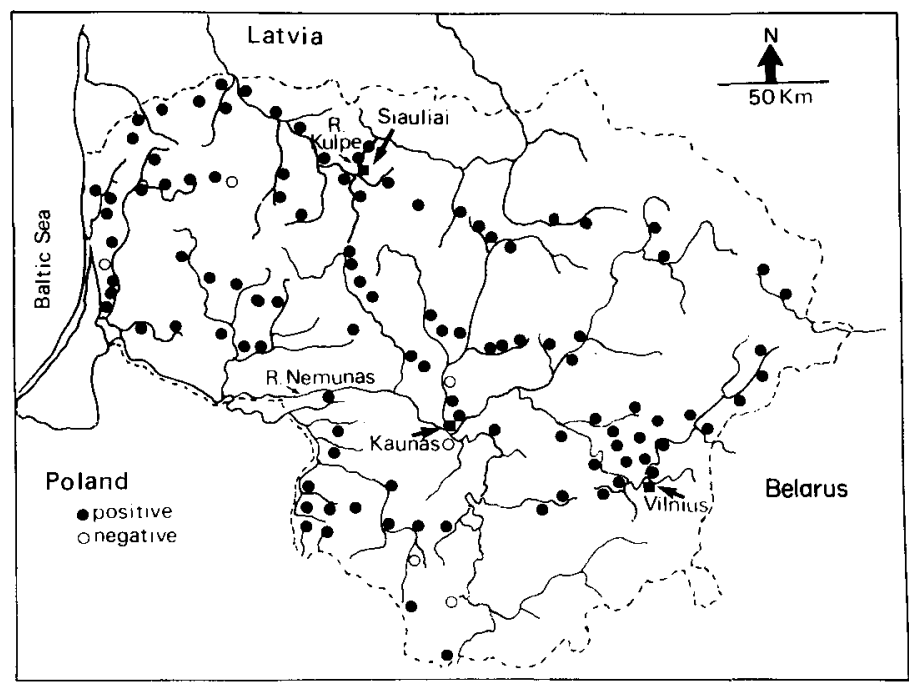

spraints per sprainting site was 3.0.

Habitat was considered as ideal for the provision of cover at 44 per cent of sites and as of poor quality at 15 per cent. Cover was largely provided by very dense scrub dominated by Salix and Alnus, mixed riparian woodland and the abundant burrows of beavers Castor fiber. Habitat considered as poor largely comprised small canalized streams lacking bankside vegetation. Signs of organic pollution were noted at 29 sites and was severe in, for example, the River Nemunas flowing through the town of Kaunas and the River Kulpe near Siauliai. Otter spraints found at the latter site contained only frog remains, the river being deoxygenated and fishless.

\section{Discussion}

The otter is still widely distributed in Lithuania, signs being found at 95 per cent of 112 stations surveyed and in all types of wetland from field drains and urban river stretches, including the edge of the capital, Vilnius, to fish ponds. It is typical of regions with widespread populations (e.g. Chapman and Chapman, 1982) that otters utilize waterways irrespective of apparent habitat quality. The mean level of marking (3.0 spraints per sprainting site) is almost identical to that found on rivers in Wales, where otters are widely distributed (from data in Mason and Macdonald, 1993).

A number of factors favour the survival of a widespread population. With only limited and localized industry and with generally lowinput agriculture, water pollution levels appear generally to be very low. While in some western European countries otters are thought to be affected by wind-borne contaminants such as PCBs (Olsson and Sandegren, 1991), northerly winds dominate over the Baltic States. Although many rivers in Lithuania have been canalized, there is still an abundance of rivers with impenetrable bankside cover and the density of waterways within the country allows for free mobility between different aquatic habitat types. River straightening schemes have now ceased and small natural streams are protected. There are about 70 hydrological and ichthyological reserves in the country.

The high beaver population may benefit otters, which can make use of beaver lodges and burrows for additional shelter. However, while otters have been protected in Lithuania since 1975 (Mickevičus, 1993), beavers are widely trapped and trappers estimate that 10 per cent of the animals caught are otters. According to the Environmental Protection Department, about 2000 beavers are legally 
trapped annually but poaching still occurs. Therefore beaver trapping poses a serious threat to otters as it does in neighbouring Latvia where J. Ozolinš (pers. comm.) estimated that about 1500 otters were trapped over the hunting seasons of 1987/88-1990/91.

Otter mortality due to road traffic, a problem in countries such as Denmark and Finland (Madsen, 1990; Skarén, 1992), is uncommon in Lithuania because traffic is light, due largely to the high cost of fuel. It is not known, however, how many animals drown in fish traps, a mortality factor that can be greatly reduced by the introduction of stop-grids for the entrances of fyke nets (Madsen et al., 1992).

\section{Conclusion}

This survey has demonstrated that the otter population of Lithuania is widespread and contiguous with the thriving population in Latvia and Byelorussia, although there is unfortunately no survey information from adjacent areas of Russia. The region, however, clearly represents a European stronghold for this species of international significance. A more detailed survey and further ecological investigations into the species are required. Such studies are currently hampered by a severe shortage of funds, which could be alleviated by only modest inputs of resources from the west. Co-operation between the Baltic States and Byelorussia in the formulation of a conservation strategy is essential. Efforts could also be made to reduce otter mortality in beaver traps.

\section{Acknowledgments}

We thank the company 'Lietuvos kuras' for financing the survey and the British Council for travel funds for S.M.M. and C.F.M. We also thank Danute, Kazimieras and the Radzvilai family for their help.

\section{References}

Chapman, P.J. and Chapman, L.L. 1982. Otter survey of Ireland 1980-1981. Vincent Wildlife Trust, London.
Foster-Turley, P., Macdonald, S. and Mason, C. (eds). 1990. Otters: An Action Plan for their Conservation. IUCN Species Survival Commission, Gland, Switzerland.

Hlaváč and Toman, A. 1993. Otter distribution and conservation in the Czech Republic. IUCN Otter Specialist Group Bull. 8, 36-37.

Kemenes, I. 1991. Otter distribution, status and conservation problems in Hungary. IUCN Otter Specialist Group Bull. 6, 20-23.

Macdonald, S.M. 1983. The status of the otter (Lutra lutra) in the British Isles. Mammal Rev. 13, 11-23.

Madsen, A.B. 1990. Oddere Lutra lutra og trafik. Flora og Fauna, 96, 39-46.

Madsen, A.B., Christensen, N.C. and Jacobsen, L. 1992. Odderens (Lutra lutra L.) forekomst i Danmark 1991 og udviklingen i bestanden 1986-1991. Flora og Fauna, 98, 47-52.

Maldžiūnaite, S. 1960. Udry paplitimas Lietuvos teritorijoje ir ju mityba. Lietuvos TSR MA darbai, N 3(23), Ser. C.

Mason, C.F. and Macdonald, S.M. 1987. The use of spraints for surveying otter (Lutra lutra) populations: an evaluation. Biol. Conserv. 41, 167-177.

Mason, C.F. and Macdonald, S.M. 1993. PCBs and organochlorine pesticide residues in otter (Lutra lutra) spraints from Welsh catchments and their significance to otter conservation strategies. Aquat. Conserv. 3, 43-51.

Mickevičius, E. 1993. The otter in Lithuania. IUCN Otter Specialist Group Bull. 8, 29-31.

Olsson, M. and Sandegren, F. 1991. Otter survival and toxic chemicals - implication for otter conservation programmes. In Proc. Vth. Int. Otter Colloqu. (eds. C. Reuther and R. Röchert), Habitat, 6, 191-200.

Ozolinš, J. and Rantinš, M. 1992. The distribution and habitat conditions of the otter (Lutra lutra) in Latvia. Proc. 1st. Baltic Theriol. Conf., Tartu, 186-195.

Sidorovich, V.E. 1990. Demografya vidri (Lutra lutra L.). Akademya nauk SSSR, Ekologya, 4, 64-69.

Skarén, U. 1992. Analysis of one hundred otters killed by accidents in central Finland. IUCN Otter Specialist Group Bull. 7, 9-12.

K. Baranauskas and E. Mickevičius, Institute of Ecology, Akademijos 2, Vilnius 2600, Lithuania.

S. M. Macdonald and C. F. Mason, Department of Biology, University of Essex, Colchester, UK. 